\title{
Insulin treatment and cardiovascular disease; friend or foe? A point of view
}

\author{
M. J. Muis*†, M. L. Bots*, D. E. Grobbee* and R. P. Stolk*
}

*Julius Center for Health Sciences and Primary Care, †Department of Internal Medicine, University Medical Center Utrecht, Utrecht, the Netherlands

Accepted 31 March 2004

\begin{abstract}
Background Several observational studies have shown that higher insulin levels are associated with an increased risk of cardiovascular disease. If higher endogenous insulin levels are causally related to cardiovascular disease, one might expect an increased risk of cardiovascular disease in patients treated with insulin, as this results in high circulating insulin levels. Such risk elevation might counteract the benefits of tight glucose control. Our objective was to explore the relationship between insulin therapy and cardiovascular disease in Type 1 and Type 2 diabetes mellitus using information from available literature.
\end{abstract}

Summary of comment Several experimental studies in animals and humans support the presence of a harmful effect of insulin on the vascular endothelium. In prospective follow-up studies increased insulin dosage was associated with increased risks of cardiovascular disease, although confounding by indication could not be excluded. Randomized controlled trials in diabetic patients, comparing conventional with intensive glucose-lowering treatment, although showing a reduction in microvascular disease, showed no significant difference in the incidence of cardiovascular disease. The results with respect to exposure to insulin are, however, difficult to interpret due to insufficient information on exposure to insulin levels as well as confounding by glycaemic control and body mass index. In addition, these studies were not designed to address the question whether higher insulin use relates to increased cardiovascular risk.

Conclusion Published research provides conflicting evidence as to whether exposure to high levels of exogenous insulin in diabetes mellitus affects the risk of cardiovascular disease. The currently available studies have a number of serious methodological restraints that limit accurate interpretation and conclusions in this area.

Diabet. Med. 22, 118-126 (2005)

Keywords cardiovascular diseases, insulin therapy, diabetes mellitus, insulindependent, diabetes mellitus, non-insulin-dependent, hyperinsulinaemia

Abbreviations CVD, cardiovascular disease; HDL, high-density lipoprotein; PAI-1, plasminogen activator inhibitor-1, DCCT, diabetes control and complications trial; UKPDS, United Kingdom prospective diabetes study; NO, nitric oxide; NOS, nitric oxide synthase; MAPK, mitogen-activated protein kinase.
Correspondence to: R. P. Stolk, Julius Center for Health Sciences and Primary Care, University Medical Center Utrecht D01.335, PO Box 85500, 3508 GA Utrecht, the Netherlands. E-mail: R.P.Stolk@jc.azu.nl

\section{Introduction}

Individuals with diabetes mellitus are at a two- to fourfold greater risk of cardiovascular disease (CVD) compared with those without diabetes $[1,2]$. CVD is the leading cause of death in diabetic patients. The importance of glycaemic control in 
reducing the risk of long-term diabetic complications is well documented. The Diabetes Control and Complications Trial (DCCT) in Type 1 diabetes and the United Kingdom Prospective Diabetes Study (UKPDS) in Type 2 diabetes have shown that it leads to a marked reduction in late diabetic complications $[3,4]$. As a result, worldwide, diabetes guidelines recommend ever lower targets for glucose control. Insulin treatment is intensified in Type 1 diabetes and insulin is used in an increasing proportion of those with Type 2 diabetes [5]. However, the evidence for effects on microvascular complications is much more convincing than that for macrovascular complications.

Although insulin treatment lowers glucose, it results in weight gain and increases the risk of hypoglycaemia $[3,6]$. Moreover, insulin is an anabolic hormone which, in experimental studies, has been shown to induce atherogenic effects [7]. Indeed, high endogenous insulin levels have been related to an increased cardiovascular risk in population-based observational studies [8]. One might also expect an increased risk in those treated with high doses of insulin. Therefore, the side-effects and benefits of increasing insulin doses should be weighed carefully, especially in those with Type 2 diabetes, who often use insulin doses above $100 \mathrm{IU} /$ day to achieve low $\mathrm{HbA}_{1 \mathrm{c}}$ levels $[9,10]$. Furthermore, insulin treatment in diabetes results in higher circulating insulin levels than under physiological circumstances in healthy persons [11]. After secretion by the B cell of the pancreas, insulin must first pass the liver where $50 \%$ will be broken down before it enters the systemic circulation [12]. To reach an effective level in the portal vein, treatment with subcutaneous injected insulin results in a relatively high peripheral insulin concentration compared with the situation with only endogenously secreted insulin. In this paper we focus on available evidence on the role of exposure to exogenous insulin in cardiovascular risk.

A Medline Database search was performed to identify all English-language articles of studies involving insulin use in patients with Type 1 or Type 2 diabetes mellitus in relation to cardiovascular disease.

\section{Endogenous insulin: observational evidence}

In subjects without diabetes mellitus, higher fasting insulin levels and a more marked insulin response during an oral glucose tolerance test have been associated with atherosclerotic disease risk [7]. The Paris Prospective Study, the Helsinki Policemen Study and the Busselton Study were the first three large prospective population-based studies that reported that elevated endogenous insulin is an independent predictor of coronary heart disease in men [13-15]. Whether this association is causal is still debated. A meta-analysis based on 17 prospective studies on endogenous insulin and CVD [13,15-25], concluded that hyperinsulinaemia is only a weak predictor of occurrence of CVD [8]. However, in all studies insulin levels were measured at one moment in time. Due to biological variability in endogenous insulin levels, subjects may have been misclassified in insulin exposure. Misclassification generally leads to attenuation of the associations under study, and thus the relationship between endogenous insulin and risk of CVD may actually be stronger. The question whether insulin itself or insulin resistance is responsible for the increased risk of CVD could not be answered in this meta-analysis.

The other body of evidence indicating that high levels of endogenous insulin confer cardiovascular risk is from studies among those with impaired glucose tolerance (IGT). They have increased endogenous insulin levels, usually over a longer time, due to decreased insulin sensitivity. Although they have normal fasting glucose levels and only moderately increased HbA1c levels, their cardiovascular risk is increased [26]. It is not clear if this is due to the ubiquitous presence of the insulin resistance syndrome, hyperinsulinaemia or the presence of post-prandial hyperglycaemia.

\section{Exogenous insulin: experimental evidence}

Vascular effects of insulin have been studied both in vitro and vivo. In vitro studies have focused on endothelium and inflammatory cells (mononuclear cells) as these play an important role in the process of atherogenesis $[27,28]$.

\section{In vitro findings}

Insulin may have several direct actions on the vasculature, both protective and harmful. A putative favourable effect of insulin is the production of the vasodilator nitric oxide (NO) by endothelial cells through enhancement of nitric oxide synthase (NOS). Studies performed in vitro on endothelial cells have confirmed that insulin enhances the expression of NOS inducing the release of NO [29,30]. Another favourable effect of insulin is its anti-inflammatory potential, as observed in human aortic endothelial cells in vitro [31,32]. A possible harmful effect is its potential to increase the production of endothelin, a potent vasoconstrictor and mitogen [33]. Insulin promotes adverse vascular effects by stimulating various growth factors acting through the mitogen-activated protein kinase (MAPK) signalling pathway. MAPK may also mediate the effect of insulin on vascular smooth muscle cell production of plasminogen activator inhibitor-1, which attenuates fibrinolysis [34].

\section{Findings in animals}

Several studies in animals have been performed with exogenous insulin to determine its effect on atherogenesis. A study by Stout et al. in 1970 showed that the aortas of insulin-treated rats contained significantly more triglyceride and had greater thickening of the intima than those of the control group. The thickening consisted of collagen fibres and smooth muscle cells [35]. Another study by the same group concluded that insulintreated chickens that had long-term treatment with insulin resulted in lipid-containing lesions and thickening of the arterial wall in experimental animals [36]. These findings 
suggested that hyperinsulinaemia exerted adverse effects on the vasculature in vivo [7]. A further study described the effect of exogenous hyperinsulinaemia on the atherogenesis in cholesterol-fed rabbits. No significant difference in extent or severity of atherosclerosis between insulin- and placebo-treated rabbits was shown [37].

\section{Findings in humans}

Several in vivo studies in humans have addressed the effects of exogenous insulin on vascular endothelium, with the first publication as early as 1939 [38]. Since that time both detrimental and favourable effects of insulin have been described. One of the favourable effects of insulin is the stimulation of $\mathrm{NO}$ release, via the L-arginine-nitric oxide pathway. This mechanism plays a central role in the vasodilator action of insulin $[39,40]$, which is, however, impaired in obesity [41]. Another beneficial property of insulin is its potential anti-inflammatory effect $[42,43]$.

Insulin also exerts a detrimental effect on the vasculature by stimulating the sympathetic nervous system. Short-term hyperinsulinaemia, with a distinct dose-response relationship, results in vasoconstriction by sympathetic activation [44-46]. Whether long-term hyperinsulinaemia contributes to such sympathetic activation is variable and species specific [47]. Another vasoconstrictive property of insulin is mediated by its stimulation of ET-1 release [48]. It has been reported that modest induced hyperinsulinaemia (by euglycaemic low-dose insulin clamp, mimicking fasting hyperinsulinaemia of insulinresistant states) abrogates endothelium-dependent vasodilatation in large conduit arteries [49]. It has been shown that insulin has heterogeneous effects on different arteries, therefore favourable effects on the limb microcirculation may not be extrapolated to other vessels [50].

A study in patients with an insulinoma reported no association with increased atherosclerosis [51]. However, the mean duration of disease was only 38.2 months [ \pm 4.7$]$, probably too short to initiate atherogenic effects.

In summary, although animal experiments suggest harmful effects of high insulin levels on atherosclerosis development, data from human experiments are less convincing and reflect in vitro findings showing both harmful and beneficial effects.

\section{Exogenous insulin: observational evidence}

Eight observational studies have been published on the relationship between insulin therapy and CVD (Table 1). Seven were limited to patients with Type 2 diabetes. These studies reported an increased risk of cardiovascular disease associated with insulin treatment compared with no insulin treatment. This was statistically significant in a study among Pima Indians and in one performed in Germany. Observational studies of this type are susceptible to confounding by indication, i.e. insulin is prescribed for reasons associated with increased CVD risk, notably worse glycaemic control and longer duration of diabetes. Although in most studies multivariate models were used to adjust for these confounding factors, they did not fully explain the reported associations. However, as recently seen in the hormone replacement treatment controversy between observational data (considerable benefit of HRT) and data from randomized controlled trials (no benefit, possible harm) [52], there may be considerable residual confounding in the relations from observational studies.

The only observational study in patients with Type 1 diabetes is the Epidemiology of Diabetes Interventions and Complications Study (EDIC) study, which is an observational extension of the DCCT. In EDIC no difference was found in carotid intima-media thickness between patients receiving intensive insulin treatment and those receiving conventional treatment at 1-2 years after the end of the DCCT. Recently, however, a report from the EDIC study indicated that the group who received intensive treatment during and after the DCCT (total 12 years, range 8-15) had a significantly reduced progression of carotid intima-media thickness compared with those who received regular care during the DCCT (6 years) and intensive treatment (usual care at that time) during the EDIC follow-up of 6 years. These findings suggest that the effect of intensive glucose treatment on atherosclerosis needs 6 years to become apparent [53]. Although the EDIC results do not indicate that insulin treatment increases CVD risk, those receiving intensive glucose-lowering treatment had a $10 \%$ increase in exogenous insulin use compared with those receiving regular care during 6 years. This constitutes a limited increase in exposure compared with the differences in life-long used insulin between individual patients. Moreover, no analyses were performed about the relation between the amount of insulin used and CVD.

\section{Exogenous insulin: evidence from randomized controlled trials}

There have been few randomized controlled trials comparing intensive insulin treatment with conventional insulin treatment. These trials were designed to determine the benefits of improved glucose control rather than increase in insulin dosage, and focussed on microvascular complications rather than macrovascular events. In addition, the duration of these trials is generally a few years, limiting conclusions on long-term exposure to higher exogenous insulin levels. Of the trials performed, only the Diabetes Mellitus Insulin Glucose Infusion in Acute Myocardial Infarction (DIGAMI) study focused a priori on macrovascular disease (Table 2). The results of these trials are not consistent. Direct (beneficial), neutral and inverse relations have been found between insulin treatment and macrovascular disease.

\section{Type 1 diabetes}

In the DCCT insulin dosage was $10 \%$ higher in the intensive treatment group over a period of 6.5 years. The intensive blood 
Table 1 Association of insulin treatment and cardiovascular disease in observational studies

\begin{tabular}{|c|c|c|c|c|c|c|c|}
\hline Population & No. & Age & Power* & $\begin{array}{l}\text { Years } \\
\text { follow-up }\end{array}$ & End points & $\begin{array}{l}\text { Insulin treatment and CVD risk (relative } \\
\text { risk or odds ratio) (inverse = lower CVD } \\
\text { risk, positive = higher CVD risk) }\end{array}$ & Treatment groups \\
\hline $\begin{array}{l}\text { EDIC, USA } 1993[53,69] \\
\text { DM } 1\end{array}$ & 1325 & $19-51$ & $89 \%$ & 6 & Carotid artery wall thickness & $\begin{array}{l}\text { Inverse significant } \\
\text { Progression: } 0.032 \mathrm{~mm} \text { vs. } \\
0.046 \mathrm{~mm}(P=0.01)\end{array}$ & $\begin{array}{l}\text { Conventional insulin treatment } \\
\text { Intensive insulin treatment }\end{array}$ \\
\hline $\begin{array}{l}\text { Pima Indians, USA } 1975 \text { [17] } \\
\text { DM } 2\end{array}$ & 824 & $\geq 25$ & $93 \%$ & 7.7 & ECG abnormalities & Positive significant [OR: $2.83(1.84-4.33)]$ & $\begin{array}{l}\text { Insulin treatment } \\
\text { No insulin treatment }\end{array}$ \\
\hline $\begin{array}{l}\text { Pima Indians, USA } 1975 \text { [70] } \\
\text { DM } 2\end{array}$ & 1093 & $\geq 45$ & $100 \%$ & 9 & Fatal coronary heart disease & $\begin{array}{l}\text { Positive significant } \\
\text { Incidence-rate ratio: insulin/no insulin } 3.8 \\
(1.5-9.4) \text {; oral/no treatment } 1.8(0.7-4.5)\end{array}$ & $\begin{array}{l}\text { Insulin treatment } \\
\text { No insulin treatment }\end{array}$ \\
\hline $\begin{array}{l}\text { Schwabing, Germany } 1980 \text { [71] } \\
\text { DM } 2\end{array}$ & 197 & $17-84$ & $20 \%$ & 5 & $\begin{array}{l}\text { Macrovascular events (stroke, } \\
\text { myocardial infarction, gangrene) }\end{array}$ & $\begin{array}{l}\text { Positive significant } \\
t \text {-value: } 1.98(P<0.04)\end{array}$ & Insulin dose \\
\hline $\begin{array}{l}\text { NHANES I, USA } 1971 \text { [72] } \\
\text { DM } 2\end{array}$ & 407 & 40 & $47 \%$ & 9 & Fatal cardiovascular events & $\begin{array}{l}\text { No significant difference [RR: } 1.88 \\
(0.73-4.87) \text { vs. } 1.37(0.64-2.89)]\end{array}$ & $\begin{array}{l}\text { Insulin treatment } \\
\text { No insulin treatment }\end{array}$ \\
\hline $\begin{array}{l}\text { KPNW Diabetes Registry, } \\
\text { USA } 1987 \text { [73] } \\
\text { DM } 2\end{array}$ & 9591 & $45-95$ & $100 \%$ & Retrospective & Congestive heart failure & $\begin{array}{l}\text { No significant difference [OR: } 1.47 \\
(1.17-1.85) \text { vs. } 0.82(0.68-0.98)]\end{array}$ & $\begin{array}{l}\text { Insulin treatment } \\
\text { No insulin treatment }\end{array}$ \\
\hline $\begin{array}{l}\text { Mortality in Diabetes, Italy } 1988 \text { [74] } \\
\text { DM } 2\end{array}$ & 1967 & adults & $86 \%$ & 7 & $\begin{array}{l}\text { Mortality by cardiovascular } \\
\text { disease (ischaemic heart disease } \\
\text { and cerebrovascular disease) }\end{array}$ & $\begin{array}{l}\text { No significant difference [RR: } 1.35 \\
(0.79-2.32) \text { vs. } 1.04(0.62-1.75)]\end{array}$ & $\begin{array}{l}\text { Insulin treatment } \\
\text { No insulin treatment }\end{array}$ \\
\hline $\begin{array}{l}\text { ARIC, USA } 1987 \text { [75] } \\
\text { DM } 2\end{array}$ & 1676 & $45-64$ & $100 \%$ & 8 & Coronary heart disease & $\begin{array}{l}\text { No significant difference [RR: } 2.64 \\
(1.74-4.00) \text { vs. } 1.82(1.23-2.70)]\end{array}$ & $\begin{array}{l}\text { Insulin treatment } \\
\text { No insulin treatment }\end{array}$ \\
\hline
\end{tabular}

*We estimated the power of the different studies retrospectively. 
Table 2 Association of insulin treatment and cardiovascular disease in randomized controlled trials

\begin{tabular}{|c|c|c|c|c|c|c|c|}
\hline Population & No. & Age & Power* & $\begin{array}{l}\text { Years } \\
\text { follow-up }\end{array}$ & End points & $\begin{array}{l}\text { Insulin treatment and CVD risk } \\
\text { (inverse = lower CVD risk, } \\
\text { positive = higher CVD risk) }\end{array}$ & Treatment groups \\
\hline $\begin{array}{l}\text { DCCT, USA } 1983 \text { [54] } \\
\text { DM } 1\end{array}$ & 1441 & $13-39$ & $22 \%$ & 6.5 & $\begin{array}{l}\text { Myocardial infarction, } \\
\text { stroke, amputation, CVD } \\
\text { confirmed by ECG or } \\
\text { angiography, death from CVD }\end{array}$ & $\begin{array}{l}\text { Inverse, non-significant (risk } \\
\text { reduction } 42 \% \text { with intensive } \\
\text { insulin treatment; } P<0.08 \text { ) }\end{array}$ & $\begin{array}{l}\text { Conventional insulin treatment } \\
\text { Intensive insulin treatment }\end{array}$ \\
\hline $\begin{array}{l}\text { UGDP III, USA } 1961 \text { [60] } \\
\text { DM } 2\end{array}$ & 619 & Adults & $2 \%$ & 12.5 & $\begin{array}{l}\text { Myocardial infarction, stroke, } \\
\text { CVD confirmed by ECG or } \\
\text { angiography, death from } \\
\text { CVD, sudden death, } \\
\text { hypertension, amputation }\end{array}$ & None & $\begin{array}{l}\text { Diet } \\
\text { Fixed insulin dose } \\
\text { Variable insulin dose }\end{array}$ \\
\hline $\begin{array}{l}\text { Veterans Affairs Diabetes } \\
\text { Feasibility Trial, } 1991[61,76] \\
\text { DM } 2\end{array}$ & 153 & $40-69$ & $22 \%$ & 2.25 & $\begin{array}{l}\text { Myocardial infarction, congestive } \\
\text { heart failure, stroke, amputation, } \\
\text { death from CVD, CVD confirmed } \\
\text { by ECG or angiography none }\end{array}$ & $\begin{array}{l}\text { None [risk ratio: } 1.003 \\
(0.996-1.0011)]\end{array}$ & $\begin{array}{l}\text { Conventional insulin treatment } \\
\text { Intensive insulin treatment }\end{array}$ \\
\hline $\begin{array}{l}\text { UKPDS, UK } 1977 \text { [4] } \\
\text { DM } 2\end{array}$ & 3867 & $48-60$ & $\begin{array}{l}\text { Not possible } \\
\text { to determine }\end{array}$ & $9-13$ & $\begin{array}{l}\text { Myocardial infarction, stroke, } \\
\text { amputation and death from CVD }\end{array}$ & None & $\begin{array}{l}\text { Conventional treatment } \\
\text { Intensive treatment with sulphonylureas or } \\
\text { with insulin }\end{array}$ \\
\hline $\begin{array}{l}\text { DIGAMI Study, Sweden } \\
1990[62,63] \\
\text { DM } 1 \& 2\end{array}$ & 620 & $68( \pm 9)$ & $57 \%$ & $1.6-5.6$ & $\begin{array}{l}\text { Mortality after myocardial } \\
\text { infarction }\end{array}$ & $\begin{array}{l}\text { Inverse } \\
\text { Relative mortality } \\
\text { reduction: } 28 \%(P=0.011)\end{array}$ & $\begin{array}{l}\text { Conventional treatment, no insulin unless it } \\
\text { was indicated } \\
\text { Insulin/glucose infusion, just after suspicion } \\
\text { of myocardial infarction, followed by } \\
\text { intensive insulin treatment }\end{array}$ \\
\hline
\end{tabular}

*We estimated the power of the different studies retrospectively. 
glucose control group showed a borderline significant reduction of $42 \%$ in risk in macrovascular events $[10,11,54]$. The absolute number of first major cardiovascular events was, however, small: three in the intensive treatment group vs. 14 in the conventional group. A meta-analysis of six randomized controlled trials on the comparison of intensive insulin treatment with conventional treatment on microvascular complications in young individuals with Type 1 diabetes included macrovascular complications as a secondary outcome [5459]. Intensive insulin treatment decreased the extent of macrovascular disease [odds ratio 0.55 (95\% CI 0.35-0.88) $P=0.015]$, but had no significant effect on the number of patients developing macrovascular disease or dying from macrovascular complications.

\section{Type 2 diabetes}

In the University Group Diabetes Program (UGDP) no significant differences in all-cause and CVD mortality among the three treatment groups (fixed-dose insulin regimen, variabledose insulin regimen and diet plus oral placebo regimen) were seen [60]. They reported $14 \mathrm{U} /$ day as fixed insulin treatment vs. a mean insulin dose of $44 \mathrm{U} /$ day as intensive treatment over a period of 12.5 years. In the UKPDS the effects of intensive blood-glucose control with either sulphonylurea or insulin and conventional treatment were compared for the risk of microvascular and macrovascular complications. The mean insulin dose of the intensive treatment group was $36 \mathrm{U} / \mathrm{day}$. Intensive blood glucose control resulted in a $16 \%$ reduction of myocardial infarction, which fell just short of statistical significance [4]. However, a comparison of those on insulin treatment during the study with those on oral treatment only was not published. The VADFT (Veterans Affairs Diabetes Feasibility Trial) compared standard vs. intensive insulin therapy in men with Type 2 diabetes mellitus to assess the rate of new cardiovascular events and their correlates. A difference in insulin dosage of $23 \%$ between the treatment groups was reported. There was a non-significant increase in $\mathrm{CV}$ events in the intensive treatment group, with no difference in total and cardiovascular mortality [61].

In none of the studies plasma insulin levels were reported. Because there is no simple correlation between insulin use and plasma insulin levels, the difference in insulin levels between the intervention groups cannot be estimated.

The (DIGAMI) study was a randomized trial on the effect of insulin infusion followed by insulin treatment in patients with diabetes during the acute phase of a myocardial infarction compared with usual care $[62,63]$. The study population comprised 620 subjects, $70 \%$ of those were patients with Type 2 diabetes. Analyses for Type 1 and 2 diabetes separately were not reported. The authors reported that insulin-glucose infusion followed by a multi-dose insulin regimen improved long-term prognosis in diabetic patients with acute myocardial infarction. There was a $28 \%(P=0.027)$ relative mortality reduction after 3.4 years in favour of the insulin infusion group compared with the usual care group. It remains to be established whether improved metabolic control by insulin or the vasodilating effects of insulin [64] caused the beneficial effects in this study.

To the best of our knowledge, analyses from these trials into the relation between exogenous insulin use (cumulative or daily dose) and risk of cardiovascular events have not been performed and may shed light on the underlying hypothesis on the balance of beneficial and adverse effects of increased insulin use.

\section{Discussion}

In routine clinical practice physicians often encounter patients on oral glucose lowering therapy or insulin treatment who either need to start insulin or require an increase in insulin dose to improve their glycaemic control $\left(\mathrm{HbA}_{1 \mathrm{c}}\right.$ level). The balance between side-effects and benefits of increase in insulin dose in these patients should be weighed carefully. We set out to review whether there is evidence that intensified insulin treatment (increasing exogenous insulin) $[11,65,66]$ counterbalances the benefit of metabolic control, leading to increased CVD risk. Experimental data (in vitro, animal and human) support both harmful and beneficial effects. Observational data with prolonged follow-up suggest that insulin treatment increases CVD risk. Results from clinical trials in patients with Type 1 or Type 2 diabetes neither support nor reject the hypothesis that insulin treatment affects CVD risk. None of the studies has, however, specifically addressed the relation between long-term exogenous insulin use and the risk of cardiovascular disease.

There are a number of methodological aspects that merit discussion. First experimental evidence is limited in that these studies are often species specific and mostly performed with supra-physiological insulin doses. For example, the insulin levels in the study by Nordestgaard in 1997 were six times higher than those described in euglycaemic clamp studies in humans [37,67]. In addition, in humans, endothelial responses to insulin seem to be heterogeneous and show vessel-specific susceptibility.

Second, evidence from observational studies may be flawed by confounding by indication [68], i.e. patients with more insulin resistance, and thus more at risk of CVD, receive higher insulin dosages. Confounding by indication may well explain part of the findings as it artificially relates insulin treatment to increased CVD risk. The confounding may not be fully removed by adjustment for these factors, notably glycaemic control and duration of diabetes. Third, evidence from most randomized controlled trials should be interpreted in the understanding that these trials were not powered for the detection of differences in cardiovascular events and were conducted over a limited number of years. In addition, differences in insulin levels across treatment groups can not be adequately extracted from the publications. Finally, the relation between cumulative insulin exposure and CVD risk cannot be investigated because of insufficient information on confounding effects of 
change in body mass index and change in glucose levels during the intervention.

Further research is clearly warranted. These studies should focus on the associations between cumulative (life time) exogenous insulin use and the incidence of cardiovascular disease. Because glycaemic control is an important confounding factor, long-term glycaemic control should be controlled for. In patients with Type 1 diabetes, these surrogate endpoints, such as carotid intima-media thickness, arterial stiffness, endothelial function, and coronary calcifications may be necessary.

In conclusion, there is conflicting evidence whether exposure to high levels of exogenous insulin in diabetes mellitus may be beneficial or adversely affect the risk of CVD. The currently available studies have important methodological limitations that limit definitive conclusions.

\section{Competing interests}

None declared.

\section{Acknowledgements}

We very much appreciate the constructive comments of Dr Joost B. L. Hoekstra (AMC Amsterdam), Dr Eelco J. P. de Koning (UMC Utrecht) and John Howell (Shamley Green, England) on earlier versions of the manuscript.

M.M. was supported by the Netherlands Organization for Health Research and Development (ZonMw).

\section{References}

1 Haffner SM, Lehto S, Ronnemaa T, Pyorala K, Laakso M. Mortality from coronary heart disease in subjects with type 2 diabetes and in nondiabetic subjects with and without prior myocardial infarction. N Engl J Med 1998; 339: 229-234.

2 Krolewski AS, Kosinski EJ, Warram JH, Leland OS, Busick EJ, Asmal AC et al. Magnitude and determinants of coronary artery disease in juvenile-onset, insulin-dependent diabetes mellitus. Am J Cardiol 1987; 59: 750-755.

3 The Diabetes Control and Complications Trial Research Group. The effect of intensive treatment of diabetes on the development and progression of long-term complications in insulin-dependent diabetes mellitus. N Engl J Med 1993; 329: 977-986.

4 UK Prospective Diabetes Study (UKPDS) Group. Intensive bloodglucose control with sulphonylureas or insulin compared with conventional treatment and risk of complications in patients with type 2 diabetes (UKPDS 33). Lancet 1998; 352: 837-853.

5 Scherbaum WA. Insulin therapy in Europe. Diabetes Metab Res Rev 2002; 18: S50-S56.

6 Purnell JQ, Hokanson JE, Marcovina SM, Steffes MW, Cleary PA, Brunzell JD. Effect of excessive weight gain with intensive therapy of type 1 diabetes on lipid levels and blood pressure: results from the DCCT. Diabetes Control and Complications Trial [published erratum appears in JAMA 1998 November 4; 280: 1484] [see comments]. JAMA 1998; 280: 140-146.

7 Stout RW. Insulin and atheroma. 20-yr perspective. Diabetes Care 1990; 13: 631-654.

8 Ruige JB, Assendelft WJ, Dekker JM, Kostense PJ, Heine RJ, Bouter LM. Insulin and risk of cardiovascular disease: a meta-analysis. Circulation 1998; 97: 996-1001.
9 Cusi K, Cunningham GR, Comstock JP. Safety and efficacy of normalizing fasting glucose with bedtime NPH insulin alone in NIDDM. Diabetes Care 1995; 18: 843-851.

10 Henry RR, Gumbiner B, Ditzler T, Wallace P, Lyon R, Glauber HS. Intensive conventional insulin therapy for type II diabetes. Metabolic effects during a 6-mo outpatient trial. Diabetes Care 1993; 16: 2131.

11 Jacobs MA, Keulen ET, Kanc K, Casteleijn S, Scheffer P, Deville W et al. Metabolic efficacy of preprandial administration of Lys(B28), Pro(B29) human insulin analog in IDDM patients. A comparison with human regular insulin during a three-meal test period. Diabetes Care 1997; 20: 1279-1286.

12 Horwitz DL, Starr JI, Mako ME, Blackard WG, Rubenstein AH. Proinsulin, insulin, and C-peptide concentrations in human portal and peripheral blood. J Clin Invest 1975; 55: 1278-1283.

13 Fontbonne A, Tchobroutsky G, Eschwege E, Richards JL, Claude JR, Rosselin GE. Coronary heart disease mortality risk: plasma insulin level is a more sensitive marker than hypertension or abnormal glucose tolerance in overweight males. The Paris Prospective Study. Int J Obes 1988; 12: 557-565.

14 Pyorala M, Miettinen H, Laakso M, Pyorala K. Plasma insulin and all-cause, cardiovascular, and noncardiovascular mortality: the 22year follow-up results of the Helsinki Policemen Study. Diabetes Care 2000; 23: 1097-1102.

15 Welborn TA, Wearne K. Coronary heart disease incidence and cardiovascular mortality in Busselton with reference to glucose and insulin concentrations. Diabetes Care 1979; 2: 154-160.

16 Pyorala K, Savolainen E, Kaukola S, Haapakoski J. Plasma insulin as coronary heart disease risk factor: relationship to other risk factors and predictive value during 9 1/2-year follow-up of the Helsinki Policemen Study population. Acta Med Scand Suppl 1985; 701: 3852.

17 Liu QZ, Knowler WC, Nelson RG, Saad MF, Charles MA, Liebow IM et al. Insulin treatment, endogenous insulin concentration, and ECG abnormalities in diabetic Pima Indians. Cross-sectional and prospective analyses. Diabetes 1992; 41: 1141-1150.

18 Despres JP, Lamarche B, Mauriege P, Cantin B, Dagenais GR, Moorjani $S$ et al. Hyperinsulinemia as an independent risk factor for ischemic heart disease. N Engl J Med 1996; 334: 952-957.

19 Orchard TJ, Eichner J, Kuller LH, Becker DJ, McCallum LM, Grandits GA. Insulin as a predictor of coronary heart disease: interaction with apolipoprotein E phenotype. A report from the Multiple Risk Factor Intervention Trial. Ann Epidemiol 1994; 4: 4045.

20 Fontbonne A, Charles MA, Thibult N, Richard JL, Claude JR, Warnet JM et al. Hyperinsulinaemia as a predictor of coronary heart disease mortality in a healthy population: the Paris Prospective Study, 15-year follow-up. Diabetologia 1991; 34: 356-361.

21 Collins VR, Dowse GK, Zimmet PZ, Tuomilehto J, Alberti KG, Gareeboo $\mathrm{H}$ et al. Serum insulin and ECG abnormalities suggesting coronary heart disease in the populations of Mauritius and Nauru: cross-sectional and longitudinal associations. J Clin Epidemiol 1993; 46: 1373-1393.

22 Hargreaves AD, Logan RL, Elton RA, Buchanan KD, Oliver MF, Riemersma RA. Glucose tolerance, plasma insulin, HDL cholesterol and obesity: 12-year follow-up and development of coronary heart disease in Edinburgh men. Atherosclerosis 1992; 94: 61-69.

23 Kuusisto J, Mykkanen L, Pyorala K, Laakso M. Hyperinsulinemic microalbuminuria. A new risk indicator for coronary heart disease. Circulation 1995; 91: 831-837.

24 Moller LF, Jespersen J. Fasting serum insulin levels and coronary heart disease in a Danish cohort: 17-year follow-up. J Cardiovasc Risk 1995; 2: 235-240.

25 Perry IJ, Wannamethee SG, Whincup PH, Shaper AG, Walker MK, Alberti KG. Serum insulin and incident coronary heart disease in middle-aged British men. Am J Epidemiol 1996; 144: 224-234. 
26 Unwin N, Shaw J, Zimmet P, Alberti KG. Impaired glucose tolerance and impaired fasting glycaemia: the current status on definition and intervention. Diabet Med 2002; 19: 708-723.

27 Laight DW, Carrier MJ, Anggard EE. Endothelial cell dysfunction and the pathogenesis of diabetic macroangiopathy. Diabetes Metab Res Rev 1999; 15: 274-282.

28 Plenz G, Robenek H. Monocytes/macrophages in atherosclerosis. Eur Cytokine Netw 1998; 9: 701-703.

29 Aljada A, Dandona P. Effect of insulin on human aortic endothelial nitric oxide synthase. Metabolism 2000; 49: 147-150.

30 Zeng G, Quon MJ. Insulin-stimulated production of nitric oxide is inhibited by wortmannin. Direct measurement in vascular endothelial cells. J Clin Invest 1996; 98: 894-898.

31 Aljada A, Ghanim H, Saadeh R, Dandona P. Insulin inhibits NFkappaB and MCP-1 expression in human aortic endothelial cells. J Clin Endocrinol Metab 2001; 86: 450-453.

32 Aljada A, Saadeh R, Assian E, Ghanim H, Dandona P. Insulin inhibits the expression of intercellular adhesion molecule-1 by human aortic endothelial cells through stimulation of nitric oxide. J Clin Endocrinol Metab 2000; 85: 2572-2575.

33 Hattori Y, Kasai K, Nakamura T, Emoto T, Shimoda S. Effect of glucose and insulin on immunoreactive endothelin-1 release from cultured porcine aortic endothelial cells. Metabolism 1991; 40: 165-169.

34 Hsueh WA, Law RE. Insulin signaling in the arterial wall. Am J Cardiol 1999; 84: 21J-24J.

35 Stout RW. Development of vascular lesions in insulin-treated animals fed a normal diet. Br Med J 1970; 3: 685-687.

36 Stout RW, Buchanan KD, Vallance-Owen J. The relationship of arterial disease and glucagon metabolism in insulin-treated chickens. Atherosclerosis 1973; 18: 153-162.

37 Nordestgaard BG, Agerholm-Larsen B, Stender S. Effect of exogenous hyperinsulinaemia on atherogenesis in cholesterol-fed rabbits. Diabetologia 1997; 40: 512-520.

38 Abramson DI, Schkloven N, Margolis MN, Mirsky IA. Influence of massive doses of insulin on peripheral blood flow in man. Am J Physiol 1939; 128: 124-132.

39 Scherrer U, Randin D, Vollenweider P, Vollenweider L, Nicod P. Nitric oxide release accounts for insulin's vascular effects in humans. J Clin Invest 1994; 94: 2511-2515.

40 Steinberg HO, Brechtel G, Johnson A, Fineberg N, Baron AD. Insulin-mediated skeletal muscle vasodilation is nitric oxide dependent. A novel action of insulin to increase nitric oxide release. J Clin Invest 1994; 94: 1172-1179.

41 Laakso M, Edelman SV, Brechtel G, Baron AD. Decreased effect of insulin to stimulate skeletal muscle blood flow in obese man. A novel mechanism for insulin resistance. J Clin Invest 1990; 85: 1844-1852.

42 Dandona P, Aljada A, Mohanty P. The anti-inflammatory and potential anti-atherogenic effect of insulin: a new paradigm. Diabetologia 2002; 45: 924-930

43 Dandona P, Aljada A, Mohanty P, Ghanim H, Hamouda W, Assian E et al. Insulin inhibits intranuclear nuclear factor kappaB and stimulates IkappaB in mononuclear cells in obese subjects: evidence for an anti-inflammatory effect? J Clin Endocrinol Metab 2001; 86: 3257-3265.

44 Rowe JW, Young JB, Minaker KL, Stevens AL, Pallotta J, Landsberg L. Effect of insulin and glucose infusions on sympathetic nervous system activity in normal man. Diabetes 1981; 30: 219-225.

45 Berne C, Fagius J, Pollare T, Hjemdahl P. The sympathetic response to euglycaemic hyperinsulinaemia. Evidence from microelectrode nerve recordings in healthy subjects. Diabetologia 1992; 35: 873879.

46 Vollenweider P, Randin D, Tappy L, Jequier E, Nicod P, Scherrer U. Impaired insulin-induced sympathetic neural activation and vasodilation in skeletal muscle in obese humans. J Clin Invest 1994; 93: 2365-2371.
47 Scherrer U, Sartori C. Insulin as a vascular and sympathoexcitatory hormone: implications for blood pressure regulation, insulin sensitivity, and cardiovascular morbidity. Circulation 1997; 96: 4104-4113.

48 Cardillo C, Nambi SS, Kilcoyne CM, Choucair WK, Katz A, Quon MJ et al. Insulin stimulates both endothelin and nitric oxide activity in the human forearm. Circulation 1999; 100: 820-825.

49 Arcaro G, Cretti A, Balzano S, Lechi A, Muggeo M, Bonora E et al. Insulin causes endothelial dysfunction in humans: sites and mechanisms. Circulation 2002; 105: 576-582.

50 Arcaro G, Solini A, Monauni T, Cretti A, Brunato B, Lechi A et al. ACE genotype and endothelium-dependent vasodilation of conduit arteries and forearm microcirculation in humans. Arterioscler Thromb Vasc Biol 2001; 21: 1313-1319.

51 Leonetti F, Iozzo P, Giaccari A, Sbraccia P, Buongiorno A, Tamburrano $\mathrm{G}$ et al. Absence of clinically overt atherosclerotic vascular disease and adverse changes in cardiovascular risk factors in 70 patients with insulinoma. I Endocrinol Invest 1993; 16: 875-880.

52 Grodstein F, Clarkson TB, Manson JE. Understanding the divergent data on postmenopausal hormone therapy. N Engl J Med 2003; 348: 645-650.

53 Nathan DM, Lachin J, Cleary P, Orchard T, Brillon DJ, Backlund JY et al. Intensive diabetes therapy and carotid intima-media thickness in type 1 diabetes mellitus. N Engl J Med 2003; 348: 2294-2303.

54 Diabetes Control and Complications Trial. Effect of intensive diabetes management on macrovascular events and risk factors in the Diabetes Control and Complications Trial. Am J Cardiol 1995; 75: 894-903.

55 Brinchmann-Hansen O, Dahl-Jorgensen K, Sandvik L, Hanssen KF. Blood glucose concentrations and progression of diabetic retinopathy. The seven year results of the Oslo study. BMJ 1992 ; 304: 19-22.

56 Feldt-Rasmussen B, Mathiesen ER, Jensen T, Lauritzen T, Deckert T. Effect of improved metabolic control on loss of kidney function in type 1 (insulin-dependent) diabetic patients: an update of the Steno studies. Diabetologia 1991; 34: 164-170.

57 Holman RR, Dornan TL, Mayon-White V, Howard-Williams J, Orde-Peckar C, Jenkins L et al. Prevention of deterioration of renal and sensory-nerve function by more intensive management of insulindependent diabetic patients. A two-year randomised prospective study. Lancet 1983; 1: 204-208.

58 Lawson ML, Gerstein HC, Tsui E, Zinman B. Effect of intensive therapy on early macrovascular disease in young individuals with type 1 diabetes. A systematic review and meta-analysis. Diabetes Care 1999; 22: B35-B39.

59 Reichard P, Pihl M. Mortality and treatment side-effects during long-term intensified conventional insulin treatment in the Stockholm Diabetes Intervention Study. Diabetes 1994; 43: 313-317.

60 Effects of hypoglycemic agents on vascular complications in patients with adult-onset diabetes. VIII. Evaluation of insulin therapy: final report. Diabetes 1982; 31 (Suppl. 1): S1-81.

61 Abraira C, Colwell J, Nuttall F, Sawin CT, Henderson W, Comstock JP et al. Cardiovascular events and correlates in the Veterans Affairs Diabetes Feasibility Trial. Veterans Affairs Cooperative Study on Glycemic Control and Complications in Type II Diabetes. Arch Intern Med 1997; 157: 181-188.

62 Malmberg K, Ryden L, Efendic S, Herlitz J, Nicol P, Waldenstrom A et al. Randomized trial of insulin-glucose infusion followed by subcutaneous insulin treatment in diabetic patients with acute myocardial infarction (DIGAMI study): effects on mortality at 1 year. J Am Coll Cardiol 1995; 26: 57-65.

63 Malmberg K, Norhammar A, Wedel H, Ryden L. Glycometabolic state at admission: important risk marker of mortality in conventionally treated patients with diabetes mellitus and acute myocardial infarction. long-term results from the Diabetes and Insulin-Glucose Infusion in Acute Myocardial Infarction (DIGAMI) study. Circulation 1999; 99: 2626-2632. 
64 Sundell J, Nuutila P, Laine H, Luotolahti M, Kalliokoski K, Raitakari $\mathrm{O}$ et al. Dose-dependent vasodilating effects of insulin on adenosinestimulated myocardial blood flow. Diabetes 2002; 51: 1125-1130.

65 Hayford JT, Thompson RG. Free and total insulin integrated concentrations in insulin dependent diabetes. Metabolism 1982; 31: 387397.

66 Rizza RA, Gerich JE, Haymond MW, Westland RE, Hall LD, Clemens $\mathrm{AH}$ et al. Control of blood sugar in insulin-dependent diabetes: comparison of an artificial endocrine pancreas, continuous subcutaneous insulin infusion, and intensified conventional insulin therapy. N Engl J Med 1980; 303: 1313-1318.

67 Howey DC, Bowsher RR, Brunelle RL, Woodworth JR. [Lys (B28), Pro (B29)]-human insulin. A rapidly absorbed analogue of human insulin. Diabetes 1994; 43: 396-402.

68 Grobbee DE, Hoes AW. Confounding and indication for treatment in evaluation of drug treatment for hypertension. BMJ 1997; 315: 1151-1154.

69 Epidemiology of Diabetes Interventions and Complications (EDIC) Research Group. Effect of intensive diabetes treatment on carotid artery wall thickness in the epidemiology of diabetes interventions and complications. Diabetes 1999; 48: 383-390.

70 Nelson RG, Sievers ML, Knowler WC, Swinburn BA, Pettitt DJ, Saad MF et al. Low incidence of fatal coronary heart disease in Pima
Indians despite high prevalence of non-insulin-dependent diabetes. Circulation 1990; 81: 987-995.

71 Janka HU, Ziegler AG, Standl E, Mehnert H. Daily insulin dose as a predictor of macrovascular disease in insulin treated non-insulindependent diabetics. Diabetes Metab 1987; 13: 359-364.

72 Kleinman JC, Donahue RP, Harris MI, Finucane FF, Madans JH, Brock DB. Mortality among diabetics in a national sample. Am J Epidemiol 1988; 128: 389-401.

73 Nichols GA, Hillier TA, Erbey JR, Brown JB. Congestive heart failure in type 2 diabetes: prevalence, incidence, and risk factors. Diabetes Care 2001; 24: 1614-1619.

74 Bruno G, Merletti F, Boffetta P, Cavallo-Perin P, Bargero G, Gallone $\mathrm{G}$ et al. Impact of glycaemic control, hypertension and insulin treatment on general and cause-specific mortality: an Italian populationbased cohort of type II (non-insulin-dependent) diabetes mellitus. Diabetologia 1999; 42: 297-301.

75 Saito I, Folsom AR, Brancati FL, Duncan BB, Chambless LE, McGovern PG. Nontraditional risk factors for coronary heart disease incidence among persons with diabetes: the Atherosclerosis Risk in Communities (ARIC) Study. Ann Intern Med 2000; 133: 81-91.

76 Abraira C, McGuire DK. Intensive insulin therapy in patients with type 2 diabetes: implications of the Veterans affairs (VA CSDM) feasibility trial. Am Heart J 1999; 138: S360-S365. 